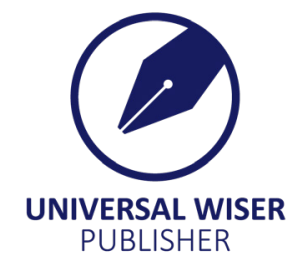

\title{
Urban Agriculture in Ethiopia: An Overview
}

\author{
Amsalu Woldie Yalew
}

Email: amsalueth@gmail.com

\begin{abstract}
Urban agriculture has recently gained attention in many developing countries following their rapid urbanization. This paper attempts to give an overview of urban agriculture in Ethiopia. It particularly synthesizes the existing evidence on the role of urban agriculture in the overall agricultural sector, urban economy, and urban employment based on data from official reports and statistical surveys. Albeit being scant, the available evidence shows that urban agriculture makes considerable contributions, particularly, seen in light of the low level of urbanization in the country. The review however reveals there exist gaps in terms of institutional and policy support for urban agriculture. The paper, therefore, tries to shed lights on the current and expected socio-economic trends that will raise the relevance of the sector. Future research, especially, on the macroeconomic aspects of the sector are highly needed. Such research and evidence will help decisionand policy-makers to embrace the concept of urban agriculture in formulating sectoral, regional, and national economic policies.
\end{abstract}

Keywords: urban agriculture, urban economy, urban employment, Ethiopia

\section{Introduction}

The increasing proportion of world urban population in the past decades ${ }^{[1-2]}$ is also accompanied by the urbanization of poverty ${ }^{[3-4]}$. Against this backdrop, many countries starts considering urban (and peri-urban) agriculture as a viable urban livelihood strategy ${ }^{[5-7]}$. Urban agriculture (UA hereafter) complements the conventional (rural) agriculture to enhance national food security ${ }^{[7]}$, contributes to the social, economic and ecological objectives of urban development ${ }^{[7-8]}$, connects consumers directly to farms and thus reduces agricultural trade margins ${ }^{[9]}$, and serves opportunities to use urban resources efficiently ${ }^{[10]}$. UA has a pivotal role to create sustainable and climate-friendly urban centers as it integrates multiple resources such as land, water, waste and energy ${ }^{[11-12]}$. As such, UA (and the whole urban food system in general) has the potential to strengthen national and international efforts to advance the Sustainable Development Goals (SDGs) ${ }^{[13-14]}$. Consequently, UA is gaining increasing attention throughout the developing world ${ }^{[6,15]}$ where both the rates of urbanization $^{[1]}$, and the number of underprivileged and food insecure inhabitants ${ }^{[14]}$ are high.

Ethiopia is a case in point. The country is undergoing through rapid rates of urbanization (ca. $4.6 \%$ annul urban population growth rate $)^{[1]}$, and rising food prices and living $\operatorname{costs}^{[16]}$. As such, UA will have a substantial role in fostering sustainable urban development agenda in the country. Despite this, however, UA in Ethiopia has gained little attention from the scientific research community. The topic is both under researched and very recent (see, for example, [17-21]). The tiny literature on UA in Ethiopia is dominated by gray literature and micro-level analysis, i.e., on a sample of households in a specific urban center. The existing body of literature, therefore, provides little information on the macroeconomic role of UA in both regional and national economies.

This study aims to fill this gap in the literature in two main ways. First, it identifies several data sources, and synthesizes the available evidence to provide an overview of UA in Ethiopia. It specifically discusses the role of UA in the overall agricultural sector (in terms of area harvested and production volumes), and in the overall urban economy (in terms of employment and GDP). Second, it presents the current and future contexts in Ethiopia that would raise UA further as a viable economic sector to deserve more attention. In both cases, to the best of my knowledge, the study is first in its kind for Ethiopia. As an overview paper, it seeks to stimulate future scientific research on the macro-economic aspects of UA, and to inform urban, regional, and national policy-makers.

The rest of the paper is organized as follows. Section 2 presents the current state of UA in Ethiopia. The section discusses UA relative to the overall agricultural sector, and urban economy. Section 3 discusses the outlooks of UA in the 
contexts of current and expected socio-economic trajectories of the country. Section 4 presents the concluding remarks of the study.

\section{The state of urban agriculture}

\subsection{Urban agriculture in the overall agriculture}

About $95 \%$ of the total crop production in Ethiopia comes from small-scale farming ${ }^{[22-23]}$ which can further be classified as rural (conventional) and urban on the basis of where the farming activities take place ${ }^{[24]}$. Nevertheless, UA is often left unreported, owing to its relative magnitude of contribution ${ }^{[24]}$ and the lack of institutions vested with clear mandates on the sector ${ }^{[21]}$. To the best of my knowledge, UA is covered and reported only in the 2001/02 Ethiopian Agricultural Enumeration Survey ${ }^{[24]}$. We will therefore depend on the same report in order to glean the glimpse of UA in the overall agricultural production, and depict in Table 1 below.

Table 1. The share of UA in total smallholder crop holders, area, and production in 2001/02

\begin{tabular}{cccc}
\hline $\begin{array}{c}\text { Crop } \\
\text { Type }\end{array}$ & $\begin{array}{c}\text { Holders } \\
(\%)\end{array}$ & $\begin{array}{c}\text { Area } \\
(\%)\end{array}$ & $\begin{array}{c}\text { Production } \\
(\%)\end{array}$ \\
\hline Cereals & 1.61 & 1.57 & 0.99 \\
Pulses & 0.59 & 0.96 & 0.44 \\
Oilseeds & 0.64 & 1.81 & 1.55 \\
Vegetables & 0.51 & 2.19 & 1.00 \\
Roots \& Tubers & 0.41 & 1.20 & 0.48 \\
Fruits \& Stimulants & 1.56 & 4.33 & 7.90 \\
\hline Source: Author's calculation from [24] & & &
\end{tabular}

Source: Author's calculation from [24]

Accordingly, in the harvest season of 2001/02, UA covered about 155,249 ha of harvested crop area yielding a total of 156,763 tons of crops $^{[24]}$. When we see its contribution relative to the overall crop production, the shares vary from hardly $0.5 \%$ (e.g., in pulses, and roots) to $7.9 \%$ (e.g., in fruits). One shall take into account the low proportion of urban population living in urban areas which was ca. $15 \%$ in $2001^{[1]}$ while interpreting these shares of UA in the overall agriculture. As such, it can be argued that UA makes non-negligible contributions to the country's agricultural sector.

\subsection{Urban agriculture in urban economy}

The role of UA in urban economy can be seen, among many others, in terms of its share in gross domestic product (GDP), informal sector, or number of Micro and Small Enterprises (MSEs) in urban centers. In the year 2002, UA makes up to $1.51 \%$ of the total business establishments and $4.28 \%$ of the total gross value of income from urban informal sector $^{[25]}$. Per contra, among the total 490,010 MSEs which were operating in 2015/16, the 58,008 MSEs (11.84\%) were engaged with $\mathrm{UA}^{[26]}$. As depicted in Figure 1, the number of MSEs involving UA is increasing particularly in recent years.

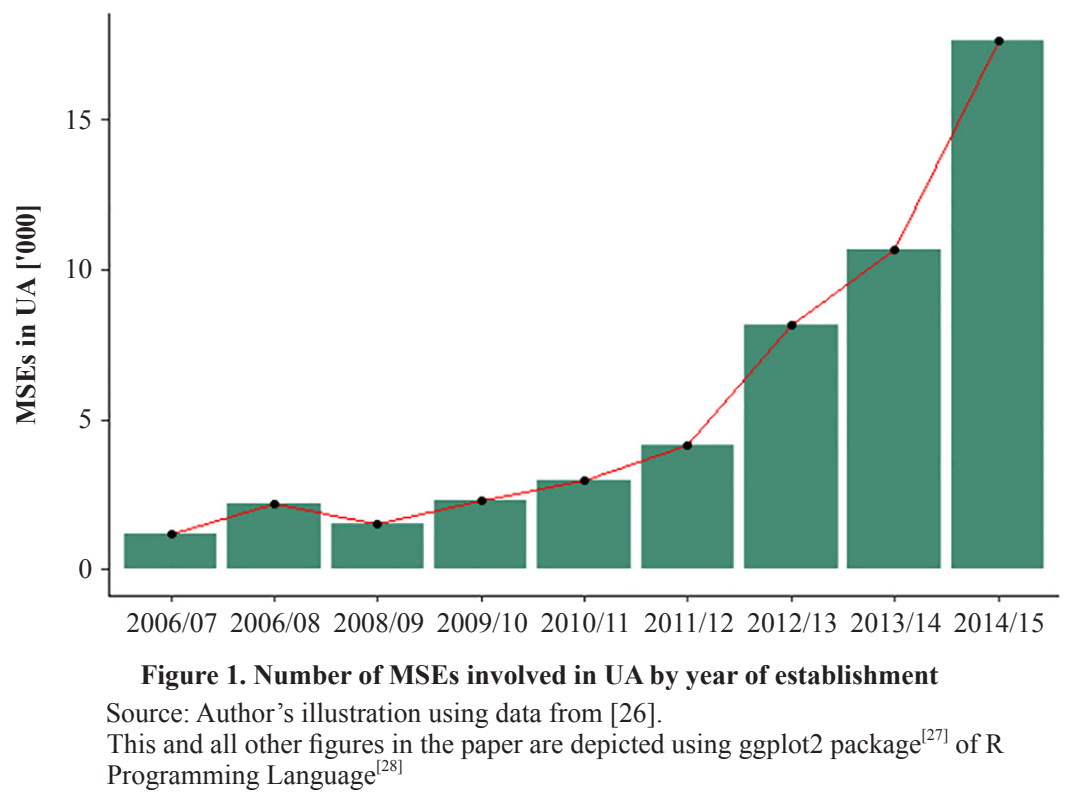


Related to MSEs are Growth Medium Enterprises (GMEs) which are rather between MSEs and big firms. There were about 5,050 GMEs operating in Ethiopia by $2015 / 16$ of which $5.52 \%$ were engaged with $\mathrm{UA}^{[26]}$. The GMEs in UA have registered a total capital of US\$ 17.5 million by $2016^{[26]}$. UA is also a source of labor income to both self-and paidemployment ${ }^{[29]}$. For instance, only to paid employees, UA generated average annual total wage bill of US\$ 77 million in the past decade ${ }^{[29]}$.

We can also examine UA's contribution in terms of GDP. On average, between 2010/11 and 2015/16, agriculture contributed to ca. $1.3 \%$ of the total GDP of the capital city Addis Ababa ${ }^{[30]}$. It is important to note here that Addis Ababa (with $100 \%$ urban population) is the biggest political, industrial and commercial center of the country partly explaining the small share of agriculture in its overall GDP.

\subsection{Urban agriculture in urban employment}

Ethiopia is an agrarian country. More than $75 \%$ of the country's total labor force is employed in agriculture ${ }^{[31]}$. In tandem with the proportion of urban population, the share of urban employment in the national employment figures has increased from $11 \%$ in 1999 to $15 \%$ in $2013^{[31-32]}$. Urban employment in agriculture has particularly increased from 318,693 (1999) to 446,500 (2005), and then to $864,186(2013)^{[31-33]}$. In relative terms, employment in agriculture made up to $11.8 \%$ (1999) to $13 \%$ (2005), and then to $13.5 \%$ (2013) of total urban employment ${ }^{[31-33]}$.

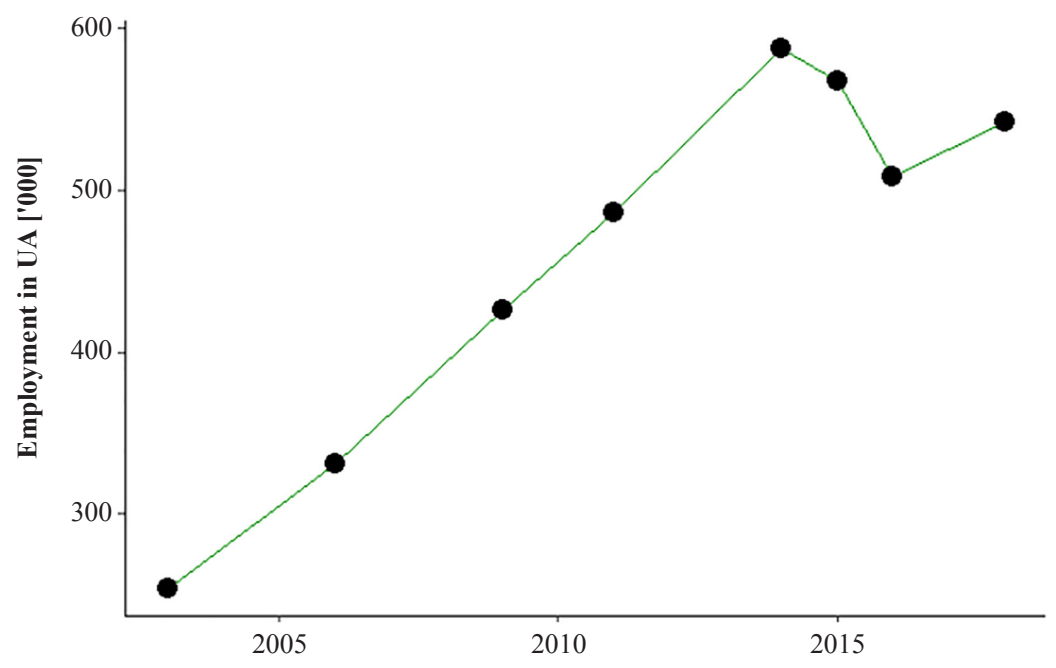

Figure 2. Trends of employment in UA in Ethiopia

Source: Author's illustration based on data from various years of UEUS

The Urban Employment and Unemployment Surveys ${ }^{[29,34-35]}$ also show an increasing trend of urban employment. For instance, it increased from 2,858,018 in 2003 to 7,518,855 in $2018^{[29,34]}$. In the same period, although its share has declined from $9 \%$ to $7 \%$, employment in urban agricultural activities has increased from 253,793 to 542,151 persons ${ }^{[29,34]}$. [The differences in absolute and relative UA employment figures in the national labor force surveys ${ }^{[31,33]}$ and urban employment and unemployment surveys ${ }^{[2,34]}$ may be due to differences in the sample sizes covered and methods used.] On the other hand, MSEs in UA created jobs to 172,682 persons (11\% of the total in $2013 / 14)$ and 852,612 persons $(31 \%$ of the total in 2014/15) while GMEs in UA created jobs to 3,214 persons (3\% of the total in 2015/16) ${ }^{[26]}$.

\subsection{Urban agriculture in the national policies}

One may take from the previous discussions that UA is important but untapped economic sector in Ethiopia. Today, UA is a part-time job to the majority of the urban farmers ${ }^{[24]}$ while it continues to employ as same traditional methods of farming as the rural agriculture ${ }^{[17-18]}$ where both labor and land are relatively abundant. As a result, in Ethiopia, crop yields in UA are far below than crop yields in rural agriculture ${ }^{[24]}$ in contrast to the experiences elsewhere ${ }^{[64]}$.

The fact that UA is yet unexploited opportunity in Ethiopia partly accrues to the lack of proper policy and legal frameworks with regard to $\mathrm{it}^{[2]}$. UA is not explicitly mentioned in the country's policy documents of the $1990 \mathrm{~s}^{[36]}$, and in the National Urban Development Policy ${ }^{[37]}$. Neither it is explicit within the most recent Agriculture Sector Policy and Investment Framework ${ }^{[23]}$ nor in the last three five years macroeconomic plans (cf., [38-40]).

The lack of policy and legal framework to UA implies two major issues. First, it affects the allocation (and property rights) of land for UA as it competes with other urban land uses, such as, green spaces, parking lots and playgrounds ${ }^{[17-19,41]}$. 
Second, it influences the number and capacity of wastewater treatment plants ${ }^{[20,42]}$ which in turn determines the quantity and quality of fresh and wastewater available to $\mathrm{UA}^{[17,19]}$. For instance, about 70 to 75 percent of the organic decomposable waste in the city of Addis Ababa is simply dumped to landfill or dumpsite ${ }^{[43]}$ while only 20 percent of the city's wastewater is used to irrigate $\mathrm{UA}^{[42]}$. Of course, recognizing the importance of the sector, some big urban areas (e.g., Addis Ababa, and Mekelle) have recently started establishing a separate department for $\mathrm{UA}^{[17,36]}$. However, there is still low awareness amongst policy makers about the importance of $\mathrm{UA}^{[19]}$ which roots to the lack of concrete national UA policy framework ${ }^{[21]}$.

\section{The outlooks of urban agriculture}

There is ample reasons to regard UA as important economic sector. This is particularly true in light of the current and expected dynamics in the Ethiopian economy. First, unemployment, poverty, and inequality are still major economic problems in urban areas ${ }^{[29,44]}$. Urban unemployment has recently shown a sign of increase, for instance, from $16.9 \%$ in 2016 to $19.1 \%$ in $2018^{[29]}$. In parallel, there is a growing number of extreme poor living in urban areas while inequality (measured by Gini-coefficient) in urban areas $(0.38)$ is by far higher than in rural areas $(0.28)^{[44]}$. Second, food prices in Ethiopia are rising over time ${ }^{[45-46]}$. The food price index has increased by more than two folds in the last decade ${ }^{[16]}$. This is explained partly by the low level of agricultural productivity ${ }^{[22]}$ not growing on a par with food demand driven by population ${ }^{[16]}$ and income ${ }^{[45]}$ growth. Food price changes (or shocks) impinge on real income, and eventually on the poverty status of urban households ${ }^{[47]}$. A recent report corroborates this, and finds urban poor in Ethiopia are becoming increasingly vulnerable to price shocks ${ }^{[44]}$.

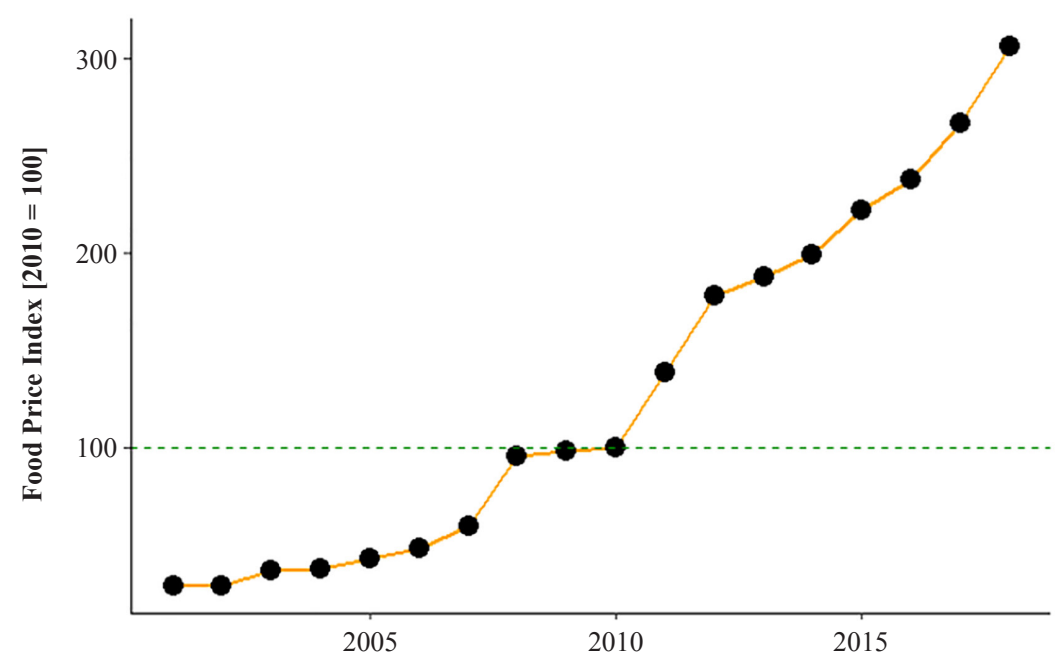

Figure 3. Food price indices in Ethiopia $(2010=100)$

Source: Author's illustration using data from [16]

Third, as in any other low-income country, the trade margins in Ethiopia are considerable due to poor transport connectivity. For instance, the difference between producer and retail (mostly urban) prices for agricultural products range between $35 \%$ for cereals to $160 \%$ for tubers and stems in $2012 / 13^{[48-49]}$, and $59 \%$ for cereals and $157 \%$ for vegetables in $2013 / 14^{[50-51]}$. Note that the highest price margins are observed in tubers and stems, fruits, and vegetables ${ }^{[48-51]}$. In addition, rural households usually provide less than a quarter of their agricultural output to urban markets retaining the rest for their own consumption and seeds ${ }^{[22]}$. Urban food security therefore could be compromised, particularly, at the times of environmental shocks such as floods and droughts. Evidence also shows that calorie consumption among urban households is less than their rural counterparts ${ }^{[44]}$. Fourth, the growth of the conventional (rural) agricultural productivity is already facing a multitude of environmental constraints. Per capita agricultural land is declining ${ }^{[22]}$ due to high population growth $^{[16]}$, a quarter of land area (which supports a third of the country's population) is severely degraded ${ }^{[52-54]}$. [The average rate of soil erosion in the Ethiopian highlands, ranges from 6 to 33 tons per hectare per year ${ }^{[54]}$. This renders an estimated annual cost of about US\$ 4.3 billion associated with land degradation that accrue to land use and land cover changes ${ }^{[53]}$.] Projected climate change and variability add other layers of risks to agriculture in Ethiopia ${ }^{[55-57]}$. In addition, a combination of factors such as the projected population ${ }^{[58]}$, climate change ${ }^{[59]}$, and competing water use demands ${ }^{[60]}$ are expected to increase water scarcity in the country. Therefore, with the current agricultural system in place, it may be 
difficult to meet the rising food demands from the population which is expected to double in the coming thirty years ${ }^{[1,16]}$.

Fifth, in urban areas of Ethiopia, headcount poverty among female-headed households is higher than among maleheaded households ${ }^{[44]}$ while unemployment rate among women is higher than men $^{[29]}$. On the other hand, the proportion of female agricultural holders is bigger in urban areas than in rural areas ${ }^{[24]}$ whereas the wage gap between male and female urban is narrow in urban agriculture compared with the wage gap in other urban industries ${ }^{[29]}$. Sixth, with the rapid rate of urbanization, urban water and organic wastes are also expected to rise. Unless it is recycled and reused, this will need more public spending on waste disposal. Seventh, urban centers are market and political centers to which many rural farmers make frequent visits for different purposes. Thus, UA can serve as a demonstration site for rural farmers.

Given these all backgrounds, UA can underpin the country's endeavor to reduce urban unemployment, poverty, and gender inequality. It can contribute to urban real income by improving direct access to food products, reducing trade margins, generating extra income, and/or saving food expenditures ${ }^{[5]}$. For instance, UA households earned an estimated income which was bigger than half of the population in Addis Ababa ${ }^{[41]}$. That was even without including the value of own-consumption. Moreover, 50\% of the sample UA households have had an estimated monthly income bigger than that of $70 \%$ of the employed population ${ }^{[41]}$. The findings are also comparable with experiences from Lome, the capital city of Togo, where vegetable growers earn a net monthly income comparable to a monthly salary of a high-level public administrator ${ }^{[17]}$. Second, UA contributes to dampen part of the price change effects on real income and consumption among urban households as most of the agricultural products with high transaction margins (i.e., vegetables, fruits, and roots) can also grow in urban areas. See also Table 1. As such, UA can supplement urban food supply and diversify nutritional diets ${ }^{[4]}$. With regard to the evidence on gender, poverty, and employment discussed earlier, UA is a potential means to empower women economically and narrow gender inequality.

In addition to its economic importance, UA can serve as an incentive for the proper management, recycling, reuse of urban waste. [It is important to note here that the use of urban waste for UA should be complemented with guidelines to safe use of waste water use in agriculture ${ }^{[61]}$.] It can therefore promote efficient resource use and environmental sustainability in growing urban areas of Ethiopia. This is particularly appealing seen in the contexts of expected water scarcity as indicated above. UA can also facilitate the diffusion and adoption of biotechnologies into conventional (rural) agriculture.

All in all, as also evidence from elsewhere shows, UA has the potential to promote sustainable food production ${ }^{[8]}$, foster sustainable urban development ${ }^{[11]}$, and hence advance the SDGs agenda ${ }^{[13]}$ in Ethiopia. UA is generally linked to the SDGs of Zero Hunger (SDG 2), of Good Health and Well-being (SDG 3), of Reduced Inequalities (SDG 10), of Sustainable Cities and Communities (SDG 11), and of Climate Action (SDG 13) while it particularly contributes to achieve the SDG targets of 11.3 (to enhance inclusive and sustainable urbanization), of 11.6 (to improve air quality and waste management), and of 11.7 (to provide inclusive green and public spaces) ${ }^{[14]}$.

To reap better socio-economic benefits from the sector, however, the government agencies at different levels should scale up their institutional support (e.g., providing land, wastewater management plants, subsidies, and agricultural extension and credit services), and embrace UA into urban landscape planning and development policy making ${ }^{[5,13-14]}$. It is well-established argument that institutional support and quality enhance efficient use of different resources. See, for example, Sun H. et al. ${ }^{[62]}$ for how institutional quality contributes to green innovation and energy efficiency across countries. Therefore, the national and regional governments should particularly start integrating urban agriculture into their established and growing cities in the spirit of the $\mathrm{SDGs}^{[14]}$.

\section{Conclusions}

This study attempts to shed lights on UA in Ethiopia in the contexts of the present and expected dynamics of the country. It particularly highlights how UA serves a unique opportunity to diversify employment, income and dietary options for urban households, and to recycle and reuse urban wastes thereby contributing to sustainable urban development. Despite its potential, however, the sector still receives inadequate institutional and policy support. A range of measures to raise urban households' awareness on waste management and their reuse in homestead gardens are highly needed. Overall, the sector deserves a due place in the sectoral and macroeconomic plans of the country.

Notwithstanding, the study comes with limitations. The study gives neither a full picture nor a detailed analysis on the dynamics of UA and its interactions with the rest of the economic sectors. So doing was inhibited by the paucity of data. The study is also biased towards the economic aspects of UA although the social ${ }^{[14,63]}$, ecological functions and environmental co-benefits of UA could even be bigger ${ }^{[2,10-11,21]}$.

Therefore, more empirical data on the scale and impact of UA should be regularly produced, and curated to help urban 
planners and decision-makers to embrace better the concept of $\mathrm{UA}^{[5]}$ as well as stimulate further scientific research. Future research should therefore focus on a wider spectrum of socio-economic benefits of UA, and their backward and forward linkages with other sectors along with their positive (or negative) externalities to the urban environment.

\section{Supplementary material}

There is a Corrigendum Notice issued on Feb. 1st 2021 for this manuscript, in which detailed description of the changes made to originally version published on October 20, 2020 is clarified.

\section{References}

[1] UN. Population Division of the United Nations' Department of Economic and Social Affairs. World Urbanization Prospects: The 2018 Revision. 2018. Available from: https://population.un.org/wup/Download/.

[2] Pauleit, S., Pribadi, D. O., El Wafa, A. E. Peri-urban agriculture: lessons learnt from Jakarta and Addis Ababa. Field Actions Science Reports. 2019. Available from: http://journals.openedition.org/factsreports/5624.

[3] Ravallion, M., Chen, S., Sangraula, P. New Evidence on the Urbanization of Global Poverty. Population and Development Review. 2007; 33(4): 667-701.

[4] Zezza, A., Tasciotti, L. Urban agriculture, poverty, and food security: Empirical evidence from a sample of developing countries. Food Policy. 2010; 35: 265-273. Available from: doi:10.1016/j.foodpol.2010.04.007.

[5] Korth, M., Stewart, R., Langer, L., Madinga, N., Da Silva, N. R., Zaranyika, H., van Rooyen, C., De Wet, T. What are the impacts of urban agriculture programs on food security in low and middle-income countries: A systematic review. Environmental Evidence. 2014; 3: 21.

[6] De Bon, H., Parrot, L., Moustier, P. Sustainable urban agriculture in developing countries. A review. Agronomy for Sustainable Development. 2010; 30: 21-32. Available from: doi:10.1051/agro:2008062.

[7] FAO. Occasional Paper 19, Agricultural management, marketing and finance. Profitability and sustainability of urban and peri-urban agriculture. Rome: Food and Agriculture Organization of the United Nations; 2007.

[8] Nicholls, E., Ely, A., Birkin, L., Basu, P., Goulson, D. The contribution of small-scale food production in urban areas to the sustainable development goals: A review and case study. Sustainability Science. 2020. Available from: doi:10.1007/s11625-020-00792-z.

[9] Martellozzo, F., Landry, J. S., Plouffe, D., Seufert, V., Rowhani, P., Ramankutty, N. Urban agriculture: A global analysis of the space constraint to meet urban vegetable demand. Environmental Research Letters. 2014; 9: 064025. Available from: doi:10.1088/1748-9326/9/6/064025.

[10] Lovell, S. T. Multifunctional Urban Agriculture for Sustainable Land Use Planning in the United States. Sustainability. 2010; 2: 2499-2522. Available from: doi:10.3390/su2082499.

[11] Skar, S. L. G., Pineda-Martos, R., Timpe, A. Urban agriculture as a keystone contribution towards securing sustainable and healthy development for cities in the future. Blue-Green Systems. 2020; 2(1): 1-27. Available from: doi:10.2166/ bgs.2019.931.

[12] Hatab, A. A., Cavinato, M. E. R., Lindemer, A., Lagerkvist, C. Urban sprawl, food security and agricultural systems in developing countries: A systematic review of the literature. Cities. 2019; 94: 129-142. Available from: doi:10.1016/ j.cities.2019.06.001.

[13] Ilieva, R. T. Urban Food Systems Strategies: A Promising Tool for Implementing the SDGs in Practice. Sustainability. 2017; 9: 170. Available from: doi:10.3390/su9101707.

[14] Indraprahasta, G. S. The potential of urban agriculture development in Jakarta. Procedia Environmental Sciences. 2013; 17: 11-19. Hernandez, M., Manu, R. Growing Greener Cities: Urban Agriculture and the Impact on SDG 11. 2018. Available from: https://sdg.iisd.org/commentary/generation-2030/growing-greener-cities-urban-agriculture-andthe-impact-on-sdg-11/.

[15] Hamilton, A. J., Burry, K., Mok, H., Barker, S. F., Grove, J. R., Williamson, V. G. Give peas a chance? Urban agriculture in developing countries. A review. Agronomy for Sustainable Development. 2014; 34: 45-73. Available from: doi:10.1007/s13593-013-0155-8.

[16] FAO. Food and Agriculture Data. Rome: Food and Agriculture Organization of the United Nations; 2020. Available from: http://www.fao.org/faostat/en/\#data.

[17] Ashebir, D., Pasquini, M., Bihon, W. Urban agriculture in Mekelle, Tigray state, Ethiopia: Principal characteristics, opportunities and constraints for further research and development. Cities. 2007; 24(3): 218-228. Available from: doi:10.1016/j.cities.2007.01.008.

[18] Duressa, T. F. Livelihood Dependence on Urban Agriculture in Addis Ababa, Ethiopia. MA Thesis, Norwegian University of Life Sciences. 2007. Available from: http://www.umb.no/noragric. 
[19] Gebremichael, D., Gebremichael, A. T., Worku, A., Abshare, M. W., Habtemariam, Y. M., Balcha, G., Gebremichael, D. Building Urban Resilience: Assessing Urban and Peri-urban Agriculture in Addis Ababa, Ethiopia. Nairobi: United Nations Environment Programme; 2014.

[20] Weldesilassie, A. B., Frör, O., Boelee, E., Dabbert, S. The Economic Value of Improved Wastewater Irrigation: A Contingent Valuation Study in Addis Ababa, Ethiopia. Journal of Agricultural and Resource Economics. 2009; 34(3): 428-449.

[21] Mulugeta, M. The Need for Policy Framework for Urban/Peri-Urban Agriculture in Ethiopia: A Reflection. Ethiopian Journal of the Social Sciences and Humanities. 2013; 9(1): 79-110.

[22] AgSS. Agricultural Sample Survey 2015/2016: Report on Area and Production of Major Crops. Addis Ababa: Central Statistics Agency; 2016.

[23] MoARD. Ethiopia's agricultural sector policy and investment framework: 2010-2020. Addis Ababa: Ministry of Agriculture and Rural Development; 2010.

[24] EASE. Ethiopian Agricultural Sample Enumeration of 2001/02. Addis Ababa: Central Statistics Agency; 2002.

[25] UISS. Report on Urban Informal Sector Sample Survey. Central Statistics Agency, Addis Ababa. Report number: 282, 2003.

[26] Federal Micro and Small Enterprise Development Agency (FMSEDA). Micro and Small Enterprises Development Sector: 2010/11-2014/15 Fiscal Year. Addis Ababa: Annual Statistical Bulletin; 2016.

[27] Wickham, H. ggplot2: Elegant Graphics for Data Analysis. New York: Springer-Verlag; 2016. Available from: https:// ggplot2.tidyverse.org.

[28] R Core Team. R: A Language and Environment for Statistical Computing. Austria: Vienna; 2020. Available from: https://www.R-project.org/.

[29] UEUS. Statistical Report on the 2018 Urban Employment Unemployment Survey. Central Statistics Agency, Addis Ababa. Report number: 586, 2018.

[30] AACPC. Real Gross Domestic Product: Forecasting Methods and Analysis for Addis Ababa City. Addis Ababa: Addis Ababa City Plan Commission; 2018.

[31] NLFS. Statistical Report on the 2013 National Labor Force Survey. Central Statistics Agency, Addis Ababa. 2013.

[32] NLFS. Statistical Report on the 1999 National Labor Force Survey. Central Statistics Agency, Addis Ababa. Report number: 225, 1999.

[33] NLFS. Report on the 2005 National Labor Force Survey. Central Statistics Agency, Addis Ababa. Report number: $305,2005$.

[34] UEUS. Report on Urban Bi-Annual Employment Unemployment Survey. Central Statistics Agency, Addis Ababa. Report number: 301, 2003.

[35] UEUS. Statistical Report Urban Employment Unemployment Survey. Central Statistics Agency, Addis Ababa. Report number: 469, 2009.

[36] MoUDHC. National Report on Housing and Sustainable Urban Development. Ministry of Urban Development, Housing, and Construction, Addis Ababa. 2014.

[37] MoFA. Urban Development Policy (Amharic Version). Ministry of Federal Affairs, Addis Ababa. 2005.

[38] MoFED. Building on Progress a Plan for Accelerated and Sustained Development to End Poverty (PASDEP): 2005/06-2009/10. Ministry of Finance and Economic Development, Addis Ababa. 2006.

[39] MoFED. Growth and transformation plan: 2010/11-2014/15. Ministry of Finance and Economic Development, Addis Ababa. 2010.

[40] NPC. Growth and transformation plan II: 2015/16-2019/20: Volume I. National Planning Commission of Ethiopia, Addis Ababa. 2016.

[41] Axumite G. Egziabher, Diana Lee-Smith, Daniel G. Maxwell, Pyar Ali Memon, Luc J. A. Mougeot, Camillus J. Sawio. Urban Farming, Cooperatives, and the Urban Poor in Addis Ababa. Cities Feeding People: An Examination of Urban Agriculture in East Africa. Ottawa: International Development Research Centre; 1994. p.146.

[42] Van Rooijen, D. J., Biggs, T. W., Smout, I., Drechsel, P. Urban growth, wastewater production and use in irrigated agriculture: a comparative study of Accra, Addis Ababa and Hyderabad. Irrigation and Drainage Systems. 2010; 24: 53-64. Available from: doi:10.1007/s10795-009-9089-3.

[43] Amera, T. Review of the Urban Environment in Ethiopia in 2008. Forum for Environment, Addis Ababa. 2010. p.61-78.

[44] PDC. Poverty and Economic Growth in Ethiopia: 1995/96-2015/16. Planning and Development Commission, Addis Ababa. 2018.

[45] NBE. National Bank Annual Report 2018-2019. National Bank of Ethiopia, Addis Ababa. 2020.

[46] CSA. Country and Regional Level Consumer Price Indices (CPI). Information No. 14. Central Statistical Agency, Addis Ababa. 2020.

[47] Dessus, S., Herrera, S., De Hoyos, R. The impact of food inflation on urban poverty and its monetary cost: some back- 
of-the-envelope calculations. Agricultural Economics. 2008; 39: 417-429.

[48] RGSS. Report on Annual Average Retail Prices of Goods and Services: 2012/13. Central Statistical Agency, Addis Ababa. 2013.

[49] AgPP. Report on Average Producers' Prices of Agricultural Products in Rural Areas: 2012/13. Central Statistical Agency, Addis Ababa. 2013.

[50] RGSS. Report on Annual Average Retail Prices of Goods and Services: 2103/14. Central Statistical Agency, Addis Ababa. 2014.

[51] AgPP. Report on Average Producers' Prices of Agricultural Products in Rural Areas: 2103/14. Central Statistical Agency, Addis Ababa. 2014.

[52] Kibret, K. S., Haileslassie, A., Mekuria, B. W., Schmitte, P. Multicriteria decision-support system to assess the potential of exclosure-based conservation in Ethiopia. Renewable Agriculture and Food Systems. 2020. Available from: https://doi.org/10.1017/S1742170520000034.

[53] Gebreselassie, S., Kirui, O. K., Mirzabaev, A. Economics of land degradation and improvement in Ethiopia. In: Nkonya E, Mirzabaev A, von Braun J. (eds.) Economics of Land Degradation and Improvement-A Global Assessment for Sustainable Development. Cham: Springer International Publishing; 2016. p.401-430. Available from: doi:10.1007/978-3-319-19168-3_14.

[54] Hurni, K., Zeleke, G., Kassie, M., Tegegne, B., Kassawmar, T., Teferi, E., Moges, A., Tadesse, D., Ahmed, M., Degu, Y., Kebebew, Z., Hodel, E., Amdihun, A., Mekuriaw, A., Debele, B., Deichert, G., Hurni, H. Soil degradation and sustainable land management in the rainfed agricultural areas of Ethiopia: An assessment of the economic implications. Report for the Economics of Land Degradation Initiative. 2015. Available from: http://www.eldinitiative.org.

[55] Yalew, A. W, Hirte, G., Lotze-Campen, H., Tscharaktschiew, S. Climate change, agriculture, and economic development in Ethiopia. Sustainability. 2018; 10: 34-64. Available from: doi:10.3390/su10103464.

[56] Evangelista, P., Young, N., Burnett, J. How will climate change spatially affect agriculture production in Ethiopia? Case studies of important cereal crops. Climatic Change. 2013; 119: 855-873. Available from: doi:10.1007/s10584013-0776-6.

[57] Bezabih, M., Di Falco, S., Mekonnen, A. On the Impact of Weather Variability and Climate Change on Agriculture: Evidence from Ethiopia. 2014.

[58] Awulachew, S. B., Merrey, D. J., Kamara, A. B., Van Koopen, B., De Vries, F. P, Boelle, E. Experiences and Opportunities for Promoting Small-Scale/Micro Irrigation and Rainwater Harvesting for Food Security in Ethiopia. Working Paper 98. Colombo, Sri Lanka: International Water Management Institute (IWMI); 2005.

[59] Taye, M. T., Dyer, E., Hirpa, F. A., Charles, K. Climate Change Impact on Water Resources in the Awash Basin. Ethiopia. Water. 2018; 10: 1560. Available from: doi:10.3390/w10111560.

[60] Arsiso, B. K., Tsidu, G. M., Stoffberg, G. H., Tadesse, T. Climate change and population growth impacts on surface water supply and demand of Addis Ababa, Ethiopia. Climate Risk Management. 2017; 18: 21-33. Available from: doi:10.1016/j.crm.2017.08.004.

[61] World Health Organization (WHO). Guidelines for the Safe Use of Wastewater, Excreta and Greywater: Volume 2 Wastewater Use in Agriculture. Geneva; 2006. Available from: https:/www.who.int/water_sanitation_health/ publications/gsuweg2/en/.

[62] Sun, H., Bless, K. E., Sun, C., Kporsu, A. K. Institutional quality, green innovation and energy efficiency. Energy Policy. 2019; 135: 111002. Available from: doi:10.1016/j.enpol.2019.111002.

[63] Horst, M., McClintock, N., Hoey, L. The Intersection of Planning, Urban Agriculture, and Food Justice: A Review of the Literature. Journal of the American Planning Association. 2017; 83(3): 277-295. Available from: doi:10.1080/019 44363.2017.1322914.

[64] McDougall, R., Kristiansen, P., Rader, R. Small-scale urban agriculture results in high yields but requires judicious management of inputs to achieve sustainability. Proceedings of the National Academy of Sciences of the United States of America. 2019; 116(1): 129-134. Available from: doi:10.1073/pnas.1809707115. 